\title{
Growth and Survival of Colorado Squawfish in the Upper Colorado River
}

\author{
D. B. OSMUNDSON \\ Colorado River Fishery Project. U.S. Fish and Wildlife Senice \\ 764 Horizon Drive, South Annex A, Grand Junction, Colorado 81506-3946. USA \\ R. J. RYEL \\ Department of Rangeland Resources, Utah State University \\ Logan, Uiah 84322-5230. USA \\ T. E. MOURNING \\ Colorado River Fishery Project, U.S. Fish and Wildlife Service
}

\begin{abstract}
Growth and adult survival rates were estimated for the endangered Colorado squawfish Prychocheilus lucius inhabiting the upper Colorado River by using data from fish captured during 1990-1995. Mean annual growth rates of fish aged 3-6 years ranged from 32.2 (age 6) to 82.0 (age 3) $\mathrm{mm} /$ year. Growth rates for older fish were highest for fish $400-449 \mathrm{~mm}$ total length, TL. (42.7 mm/year) and declined to $19.8 \mathrm{~mm} /$ year for fish $500-549 \mathrm{~mm} \mathrm{TL}$. Fish $550 \mathrm{~mm}$ and longer grew an average $9.5 \mathrm{~mm} /$ year. Survival rates for fish $550 \mathrm{~mm}$ and longer were estimated by comparing measured size distributions with simulated stable age and size distributions; these ranged from $0.83-0.87$. with the best fit at 0.85 . Though lack of historical data precludes comparisons with past growth and survival rates, our data serve as a baseline for future population monitoring efforts.
\end{abstract}

Growth and survival rates, fundamental components of most demographic studies, are essential to understanding population dynamics and requisite to formulating recovery and management strategies for endangered species. The Colorado squawfish Ptychocheilus lucius, an endangered, long-lived, cyprinid fish endemic to the Colorado River system of North America, has been the focus of much life-history research. To date, age and growth studies (e.g., Vanicek and Kramer 1969; Seethaler 1978; Hawkins 1992) have relied on standardized scale analysis techniques (e.g., Tesch 1968; Carlander 1969).

However, scales have proven unreliable for some species (Beamish and McFarlane 1987; McCarthy and Minckley 1987) and have considerably underestimated age in long-lived individuals of many western North American catostomids and cyprinids (Scoppettone 1988). Also, critical validation of aging techniques has been lacking due to a scarcity of known-age individuals. Although aging with other bony structures (e.g., vertebrae, otoliths, opercles) may corroborate results from scales, this constitutes a partial validation at best (Beamish and McFarlane 1983) and requires sacrifice of these rare animals.

Problems specific to aging Colorado squawfish with scales include lack of annulus formation for most individuals in the first year and compression and loss of outer annuli by older fish (Hawkins 1992). Although the first issue can be adjusted for, problems in distinguishing and counting outer annuli can result in many fish being assigned to ages near the age point where the method fails (Beamish and McFarlane 1983). Hawkins (1992) suggested that discrepancies in average growth increments for Colorado squawfish greater than total length $500 \mathrm{~mm}$ (TL) calculated from scales $(30 \mathrm{~mm} /$ year) and those from recaptured tagged fish (10-15 $\mathrm{mm} /$ year) were due to the negative effects of Carlin dangler tags. Indeed, Floy tags, another external tag, reduce growth in salmonids (Carline and Brynildson 1972, Mourning et al. 1994), though not in largemouth bass Micropterus salmoides (Tranquilli and Childers 1982).

The recently developed small, internally implanted passive integrated transponder (PIT) tag (Biomark, Inc., Boise, Idaho) enhances the permanent marking of individual fish and reduces or eliminates biases in growth previously ascribed to dangler tags. Burdick and Hamman (1993) detected no difference in growth between PIT-tagged fish and non-PIT-tagged controls. Further, 98$100 \%$ tag verification was realized 20-24 months after PIT tags were implanted in Colorado squawfish. 


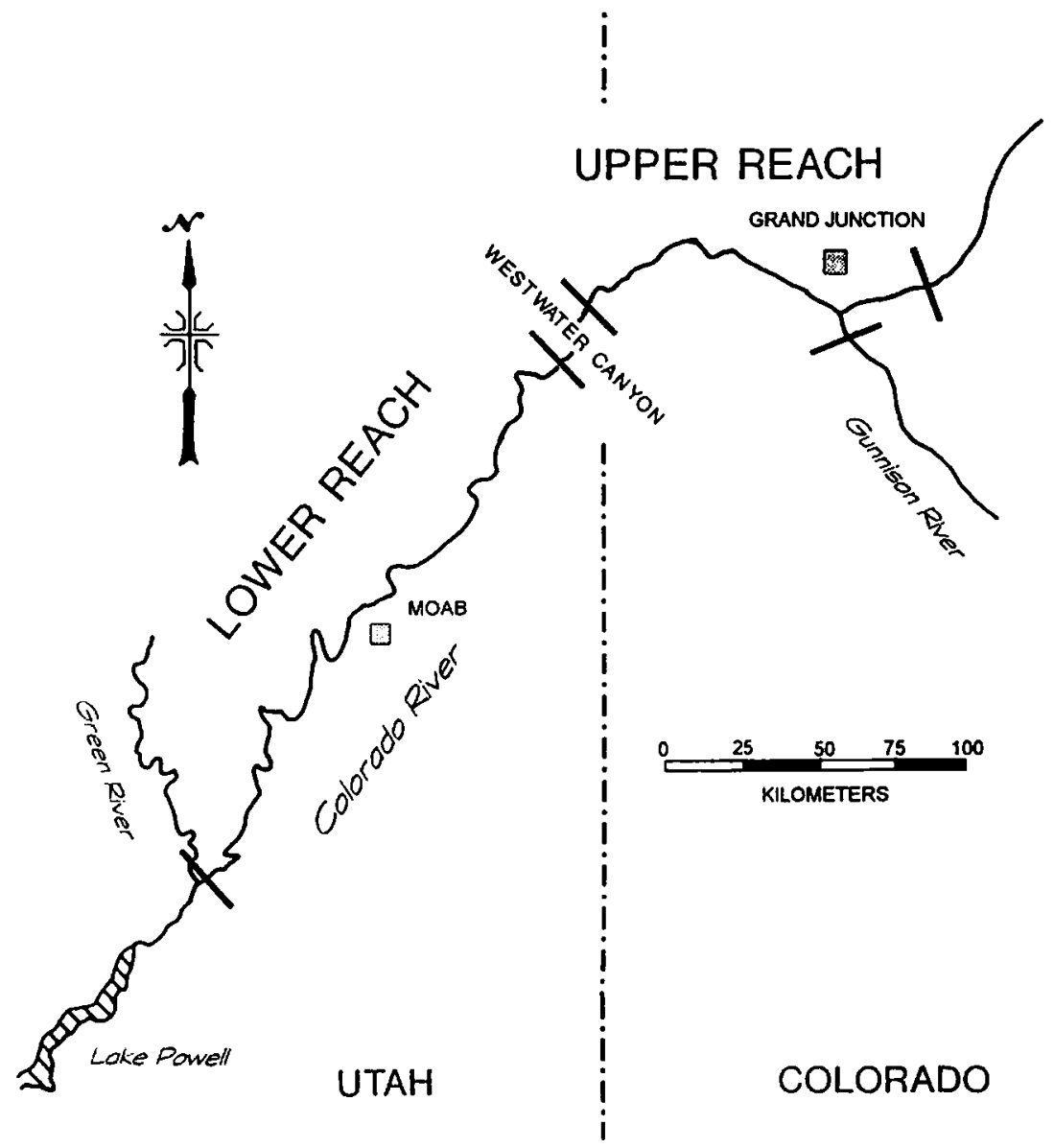

Figuke 1.-Map of the upper Colorado River study area. Transverse lines indicate boundaries of upper and lower study reaches (Westwater Canyon was not studied). Upstream-most lines mark sites of physical barriers to fish movement: no such barriers exist at other line locations.

Problems inherent in scale-based aging and growth estimation for long-lived species, such as Colorado squawfish, prompted us to refine existing growth estimates by using new mark-recapture data. Age estimates so derived also enabled us to assess rates of adult survival. Our primary objective was to refine estimates of Colorado squawfish growth rate by minimizing use of scale analyses and relying instead on recaptured PIT-tagged fish. A secondary objective was to estimate adult survival rate with an approach modified from models (c.g., Seber 1982) that use declining numbers of increasingly older fish in the population. A third objective was to estimate age of Colorado squawfish of various sizes and provide an estimate of potential longevity. In addition, we discuss the disappearance of very large individuals reported in historical accounts and mortality factors that may at present reduce survival rates.

\section{Methods}

\section{Study Area}

The study area included the occupied range (about $300 \mathrm{~km}$ of river) of the Colorado squawfish in the Colorado River upstream of the Green River confluence (Figure 1). Locations are in river kilometers (rk) from the Green River confluence (rk 0.0 ), converted from river miles mapped by Belknap and Belknap (1974). Further upstream movement is blocked seasonally by a dam at rk 298.1 and all year by another dam at rk 303.0. Upstream access to the Gunnison River, a major tributary entering at rk 275.1 , is blocked all year by a dam $3.5 \mathrm{~km}$ upstream of the mouth. Most adult Colorado squawfish live in the upper part of the study area; earlier life stages are generally found downstream. The study area was divided into upper and lower reaches based on distribution of life stages. 
Westwater Canyon (rk 181-200) served as the demarcation zone (Figure 1) and was not sampled.

\section{Fish Capture and Marking}

During late April to mid-June 1991-1994 efforts were made to capture Colorado squawfish throughout the study area. Previous radiotelemetry studies indicated high seasonal use of low-velocity, offchannel habitats as main-stem flows increased from spring runoff (Osmundson and Kaeding 1989). Trammel nets were used to quickly block mouths of backwaters, and a powerboat "drove" fish from the backwaters toward the channel, thereby ensnaring fish, an active rather than passive capture method.

Each year, three passes were made through the upper study area and two were made through the lower study area. Every backwater suspected of sheltering adult Colorado squawfish was sampled on each pass (91-104 different sites annually). In some reaches, where backwaters were rare, shorelines were electrofished with a 4.9-m johnboat equipped with a Coffelt VVP-15 (Coffelt Manufacturing. Flagstaff, Arizona) that produced pulsed DC.

Captured fish were scanned and tagged if a PIT tag was not detected. Fish were first anesthetized with tricane methanesulfonate. Tags were implanted in the body cavity with a hypodermic needle that was inserted $2-5 \mathrm{~mm}$ posterior to the base of the left pelvic fin. Five to eight scales were removed between the lateral line and dorsal fin insertion. Maximum total length (Anderson and $\mathrm{Gu}$ treuter 1983) was measured and fish were released after recovery from the anesthetic.

Our growth data were supplemented by additional records obtained from various sources, including a pilot exercise conducted in the upper reach in 1990. The Colorado Division of Wildlife (CDOW) contributed data from 1991 through 1995, and some recapture data were provided by the Utah Division of Wildlife Resources (UDWR); both agencies conduct annual spring electrofishing surveys. Records from a U.S. Fish and Wildlife Service (FWS) 1994-1996 survey of the lower 3.5 $\mathrm{km}$ of the Gunnison River and a 1995-1996 survey near rk 262 were also used. Length data collected by FWS in 1982 were used in tests for a stable age distribution.

\section{Calculation of Growth}

A combination of techniques was applied to ascertain TL at various ages. Our goal was to use measured changes of individuals as much as pos- sible and minimize reliance on scales. Recaptures of juvenile and subadult Colorado squawfish were few. however, so measurements of fish aged by various means, including scales (ages $2-7$ ), were used for young fish.

Ages 0-7.-Colorado squawfish average $7.7 \mathrm{~mm}$ long at hatching (Snyder 1981). For 1-year-old Colorado squawfish, mean TL was calculated from measurements of 73 fish seined on 28 June 1989 (about a year after hatching) from backwaters near rk 87, for which a unimodal si.e distribution indicated all were of one age-grcup. Beginning with 2-year-old fish, annual increases represent growth from one spring to the next, rather than between hatching periods or between winters. Mean TL at each age for Colorado squawfish 2-7 years old was derived from specimens aged by scales captured between 28 April and 21 June 1991-1994, primarily from the lower reach. Because hatching generally occurs in July or August, many of these fish were 1-3 months younger than the reported age.

Scale annuli were counted; the first annulus, assumed missing (e.g., Seethaler 1978; Hawkins 1992), was added to estimate age. Four to eight scales were examined from each fish and the number of annuli most frequently identified was used. We used scales from known-age pond-reared Colorado squawfish (2-4 years old) for developing our technique and later testing our accuracy.

Ages 8 and older.-For fish 8 years and older, sufficient recapture data were available for determining mean annual growth increments. Data were typically from fish with capture-recapture intervals of 1 year. However, because of lower sample sizes for fish $600 \mathrm{~mm}$ and larger, annual increments were also calculated for fish with recapture intervals of 2 or 3 years. Annual increments were averaged by size-class of fish ( $50-\mathrm{mm}$ categories) at initial capture. Analysis of variance (ANOVA) was used to test for differences in rates among sizeclasses.

Mean TL at each age was first calculated by adding the appropriate mean growth increment (based on length-class) to mean TL of the preceding age. Average TL of 7-year-old fish as determined from scales was the starting point. The process was continued to $900 \mathrm{~mm}$, roughly the upper size limit of Colorado squawfish captured in recent years.

Monte Carlo simulation based on mean and variance of growth increments for cach size-class was also used to estimate mean TL at each age. Twenty simulations were conducted with different ran- 
dom-number sequences. Mean and variance of 7-year-old fish as determined by scales was used to generate an initial size distribution. For a simulated population of $10^{3}$ fish in each age, lengths at each age were calculated based upon simulated distributions of sizes in the previous age-class. Range of ages expected for given lengths was also calculated from these simulations.

To aid in constructing growth simulations, statistical tests were conducted to determine if growth in one year was related to growth the following year (i.e., whether individual fish consistently grew more than the average) and whether mean growth in some years was greater than in other years. Contingency table analysis was conducted with fish captured in multiple years to test the relationship of individual growth between years. We used analysis of covariance (initial length as covariate) to test for differences among years for 1991-1995.

\section{Survival}

Estimates.-Survival rates were estimated for Colorado squawfish $550 \mathrm{~mm}$ and longer. We assumed that survival rates of juveniles and subadults were probably different from adults but had no way of assessing them. Estimates were limited to upper-reach adults (Figure 1) because longitudinal variation in size distributions, coupled with unequal sampling effort between reaches, could have biased whole-river length distributions. The estimates were limited to fish $550 \mathrm{~mm}$ and longer because Seethaler (1978) reported immature fish as large as $503 \mathrm{~mm}$ TL. Estimates were made with a modified Chapman-Robson approach (Seber 1982 ), in which survival is based on declining numbers of individuals by age in the population.

Because captured fish were not reliably aged, survival estimates were made by comparing lengths of captured fish with theoretical length distributions under the following assumptions (consistent with Ricker 1975): (1) survival rate is uniform with age over the range of ages examined; (2) survival rate is uniform over time and does not vary among years; (3) recruitment to the first size examined is equal among years; and (4) the sample is uniformly drawn from all ages-lengths considered (i.e., there is no effect of gear selectivity).

Theoretical length distributions (termed stable length distributions) were calculated from age distributions, assuming constant survival rates and constant recruitment into the youngest age-class (termed stable age distributions), and the generated age-length distributions (Figure 2). The sta-
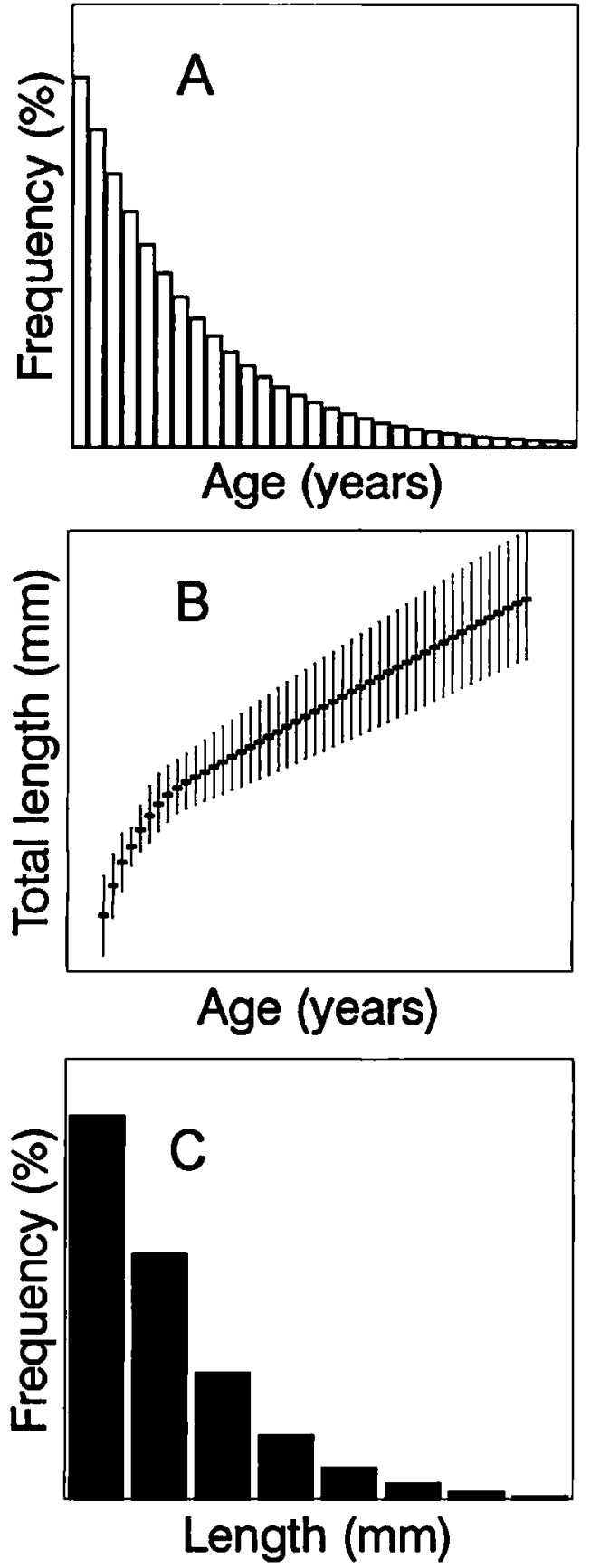

FIGURE 2.-Calculation of stable length distribution (C) from stable age distribution (A) and age-length distribution (B). The stable age distribution assumes a constant survival rate and rate of recruitment into the youngest age-class. Age-length distributions are calculated from distributions of growth increments based on total length. The stable length distribution was calculated by using relative number of fish for each length as determined by age-length frequency distribution and relative number of fish by age. 
TABLE 1.-Estimated mean total lengths (TL) and mean annual growth increments by age for age-0-7 Colorado squawfish in the Colorado River. Mean length at hatching is from Snyder (1981). Mean TL at age 1 is from measured fish assumed to be 1 year old that were seined near river kilometer 87 (measured from the mouth of the Green River) on 28 June 1989. Mean lengths of fish age 2-7 are from measurements of fish aged by scales. Insufficient captures of age-2 fish precluded estimates of increments for ages 1-2 and 2-3. Increments for fish age 7-8 were not calculated because presumptive age- 8 fish were not reliably aged.

\begin{tabular}{|c|c|c|c|c|c|c|c|}
\hline \multirow{2}{*}{$\begin{array}{c}\text { Age } \\
\text { (years) }\end{array}$} & \multirow[b]{2}{*}{$N$} & \multicolumn{3}{|c|}{ Total length (mm) } & \multirow{2}{*}{$\begin{array}{c}\text { Growth } \\
\text { period } \\
\text { (age) }\end{array}$} & \multicolumn{2}{|c|}{$\begin{array}{l}\text { Annual growth } \\
\text { increment (mm) }\end{array}$} \\
\hline & & Mean & Range & SD & & Mean & SD \\
\hline 0 & 8 & 7.7 & $7.0-8.5$ & 0.5 & $0-1$ & 63.5 & 13.6 \\
\hline 1 & 73 & 71.2 & $50-103$ & 13.6 & $1-2$ & & \\
\hline 2 & 1 & 181.0 & & & $2-3$ & & \\
\hline 3 & 3 & 232.7 & $190-259$ & 37.3 & $3-4$ & 82.0 & 56.0 \\
\hline 4 & 6 & 314.7 & $267-374$ & 41.8 & $4-5$ & 61.5 & 53.4 \\
\hline 5 & 19 & 376.2 & $326-453$ & 33.3 & $5-6$ & 47.9 & 45.3 \\
\hline 6 & 10 & 424.1 & $375-472$ & 30.6 & $6-7$ & 32.2 & 36.6 \\
\hline 7 & 7 & 456.3 & $430-479$ & 20.0 & & & \\
\hline
\end{tabular}

ble age distribution for constant survival rate $s$ was calculated as

$$
N_{i}=N_{i-1} \cdot s \cdot(1-\mathrm{g}) \text {, }
$$

where $N_{i}$ is the relative number of fish of age $i$ and $g$ is the annual rate of population growth. Simulations were conducted to select lengths for each age from age-length distributions. Lengths were randomly selected for 10,000 fish of each age, and the number of fish in 1-mm increments calculated by weighting the relative number in each age-class. Survival rates for which measured distributions did not differ significantly (Kolmogorov-Smirnov

TABLE 2.-Estimated annual growth increments for Colorado squawfish $400 \mathrm{~mm}$ total length (TL) and longer in the Colorado River. Mean increments are from measured changes in length of recaptured fish. Length-class is of fish at first capture. Mean growth increments with a letter in common are not significantly different (ANOVA, $F=$ 13.63; df $=7,119 ; P<0.00001$; Fisher's least significant difference, $P<0.05$ ). A combined average increment for fish 550-899 mm TL is also shown because mean increments among these sizes were not statistically different.

\begin{tabular}{crccc}
\hline $\begin{array}{c}\text { Length- } \\
\text { class } \\
\text { at age } i \\
(\mathrm{~mm})\end{array}$ & $N$ & Mean & Range & SD \\
\cline { 2 - 5 } & & \multicolumn{3}{c}{$\begin{array}{c}\text { Growth age } i \text { to } \\
\text { age } I(\mathrm{~mm})\end{array}$} \\
\hline $400-449$ & 6 & $42.7 \mathrm{w}$ & $28-52$ & 8.1 \\
$450-499$ & 17 & $30.1 \mathrm{x}$ & $5-68$ & 18.9 \\
$500-549$ & 24 & $19.8 \mathrm{y}$ & $4-54$ & 13.7 \\
$550-599$ & 32 & $9.5 \mathrm{z}$ & $0-31$ & 8.2 \\
$600-649$ & 21 & $8.7 \mathrm{z}$ & $0-24$ & 7.5 \\
$650-699$ & 10 & $12.5 \mathrm{zy}$ & $3-24$ & 7.9 \\
$700-749$ & 6 & $14.0 \mathrm{zy}$ & $7-22$ & 5.6 \\
$750-799$ & 3 & $10.4 \mathrm{z}$ & $5-15$ & 4.9 \\
$800-849$ & 3 & $2.7 \mathrm{z}$ & $0-5$ & 2.5 \\
$850-899$ & 5 & $5.1 z$ & $2-8$ & 2.4 \\
$550-899$ & 80 & 9.5 & $0-31$ & 7.5 \\
\hline
\end{tabular}

[K-S] one-sample test, $P>0.05$ ) from stable length distributions were considered "suitable" estimates.

Tests of assumptions.-Statistical tests were conducted to assess whether observed population structure of fish $550 \mathrm{~mm}$ and longer was consistent with the assumptions listed above. Comparisons between TL distributions in each year (1982, and 1991-1995) were made with the K-S two-sample test to assess constancy of age structure between years (see Figure 2). Stability in age structure would be consistent with constant recruitment into the youngest age-class of fish $550 \mathrm{~mm}$ and longer and constant survival among years and over ages and lengths. We compared length distributions of fish captured with trammel nets with fish that were electrofished ( $\mathrm{K}-\mathrm{S}$ two-sample test) to determine if all data could be used. We also used annual trammel-net catch rates of Colorado squawfish $\mathbf{5 5 0}$ $\mathrm{mm}$ and longer to assess (ANOVA) if abundance was relatively stable (i.e., $g \approx 0$ ) during 19911994. Though effort among net sets was unequal, average effort was assumed equal among years.

\section{Results}

\section{Growth and Age}

Growth of Colorado squawfish in the Colorado River was relatively rapid through about age 10 , when fish averaged approximately $550 \mathrm{~mm} \mathrm{TL}$ (Tables 1,2). Our estimates of mean lengths by age were similar to reports by others, but only through age 10 (Figure 3 ). Our estimate of mean age for fish $600 \mathrm{~mm}$ was 15 years; $700 \mathrm{~mm}, 25$ years; $800 \mathrm{~mm}, 32$ years. Rate of growth slowed after age 10, although an increase in rate may occur when fish are between 650 and $800 \mathrm{~mm}$; beyond 


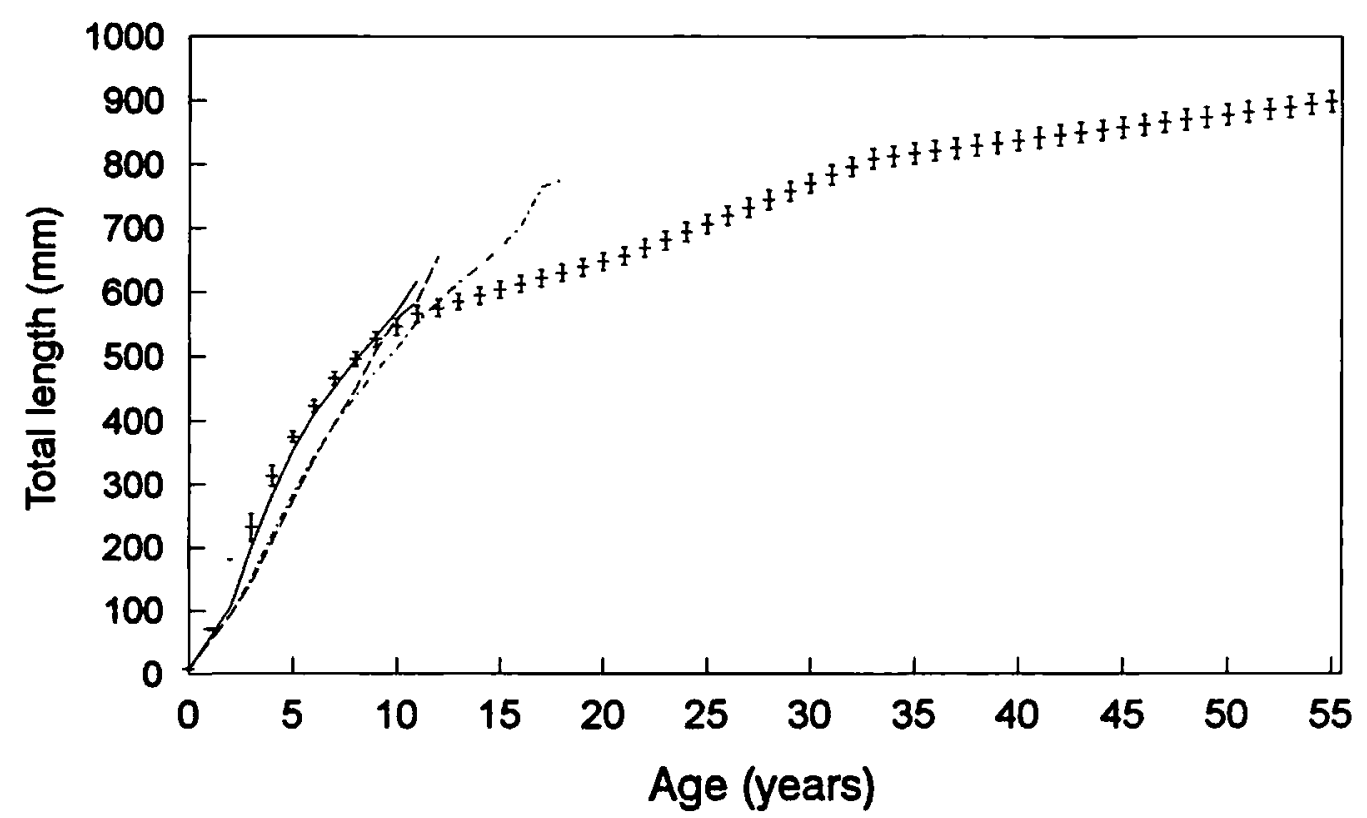

Figuri: 3.-Estimated mean length by age for Colorado squawfish in the Colorado River. Lengths calculated by four methods (see Tables 1. 2). Bars represent \pm I SE. For ages where lengths were calculated by adding mean increments to mean lengths of the preceding age (ages 8-55). SE was calculated assuming a linear combination of mean increments. Additional lines are growth curves reported by others: solid, Seethaler (1978) for the Colorado River: dash, Hawkins (1992) for the Colorado River: dot-dash, Hawkins (1992) for four rivers combined.

$800 \mathrm{~mm}$, growth appears to slow (Table 2). Differences in mean annual growth increments among all size-classes greater than $550 \mathrm{~mm}$ were, however, not statistically significant. Rate differences among years (1991-1995) were not present in fish $345 \mathrm{~mm}$ or longer (ANCOVA, $F=0.34$, df $=4$, $71, P=0.85$ ). Relationships between growth in one year and subsequent years was not indicated for fish $400 \mathrm{~mm}$ or longer $\left(x^{2}=0.024, \mathrm{df}=1, P\right.$ $=0.88$ ), i.e., most fish did not consistently grow more or less than the average.

Simulated length distributions produced mean lengths by age similar to those derived by adding mean increments (Figure 3 ) and indicate an expected range of variation by age (Figure 4a). Growth increments were log-normal within sizeclasses, and simulations used log-transformed growth rates. When growth was assumed constant for fish $550 \mathrm{~mm}$ and longer, the rate was steady, as expected, but variance in lengths for a given age was greater than when calculated increments were used (Figure 4b). Twenty simulations that used different random-number sequences produced nearly identical distributions by age.

Simulations indicated broad ranges of age for fish of similar lengths, especially for fish $550 \mathrm{~mm}$ and longer (Figure 5a). Individuals may take
$10-22($ mean $=15)$ years to reach $600 \mathrm{~mm} ; 16-$ $30($ mean $=25)$ years to reach $700 \mathrm{~mm}$; and $20-$ 40 (mean $=32$ ) years to reach $800 \mathrm{~mm}$. Similar, but even more variable, ages were indicated for a given TL when growth of fish $550 \mathrm{~mm}$ and longer was assumed constant (Figure 5b).

\section{Survival}

Tests of assumptions.-No significant differences $(P>0.05)$ existed among years in the TL distributions of fish $550 \mathrm{~mm}$ or longer captured in the upper reach 1991-1994 $(N=34,41,49,34$, respectively). Similarly, no significant differences $(P>0.05)$ were present between TL distributions for those years and for $1990(N=15)$ and 1995 $(N=44)$ under different sampling regimes. The TL distribution of 1982 fish $(N=41)$ was significantly different from $1992(P=0.028)$, but was not $(P>0.05)$ for all other years (1990-1995), suggesting essential stability during the period.

Catch rates, expressed as number of Colorado squawfish $550 \mathrm{~mm}$ on longer per net set, were compared for the period 1991-1994 (number of sets $=139,117,121,105$, respectively). No significant differences existed among years (KruskalWallis one-way ANOVA, $x^{2}=1.916, \mathrm{df}=3, P$ $=0.590$ ). 


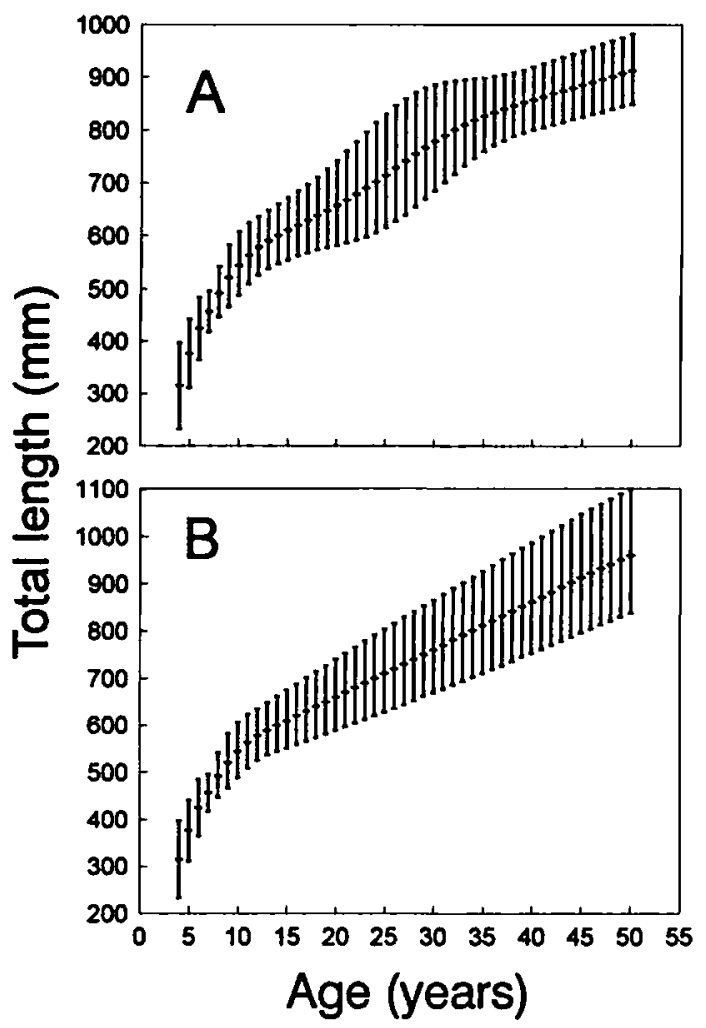

FigurF 4.-Lengths from Monte Carlo simulations using (A) size-specific growth rates as shown in Tables $I$ and 2 and (B) constant growth rate for fish $550 \mathrm{~mm}$ TL and longer (sec Table 2). Bars represent lengths of 95\% of fish of each age-group.

Differences in size distribution were, however, present between fish ( $\geq 550 \mathrm{~mm}$ ) caught in trammel nets and by electrofishing. The only data set with comparable periods and reach of capture for both methods was in 1994 in a section (rk 246275 ) of the upper reach. Captures by electrofishing $(N=13)$ included significantly $(P=0.016)$ more large fish than by trammel netting $(N=21)$, a bias consistent with observations of others (see Reynolds 1983). Although we could not test if distributions of fish caught by trammel nets were representative of the population, we assumed they were because fish were confined and actively trapped, thereby reducing or eliminating possibilities for size selectivity (i.e., differential trap shyness, escapement ability, or susceptibility to electric fields). Survival estimates were therefore calculated for fish $550 \mathrm{~mm}$ and longer from trammelnet data only.

Estimates.-For 1991-1994 data combined, suitable survival rates varied from 0.83 to 0.87 ( $P$

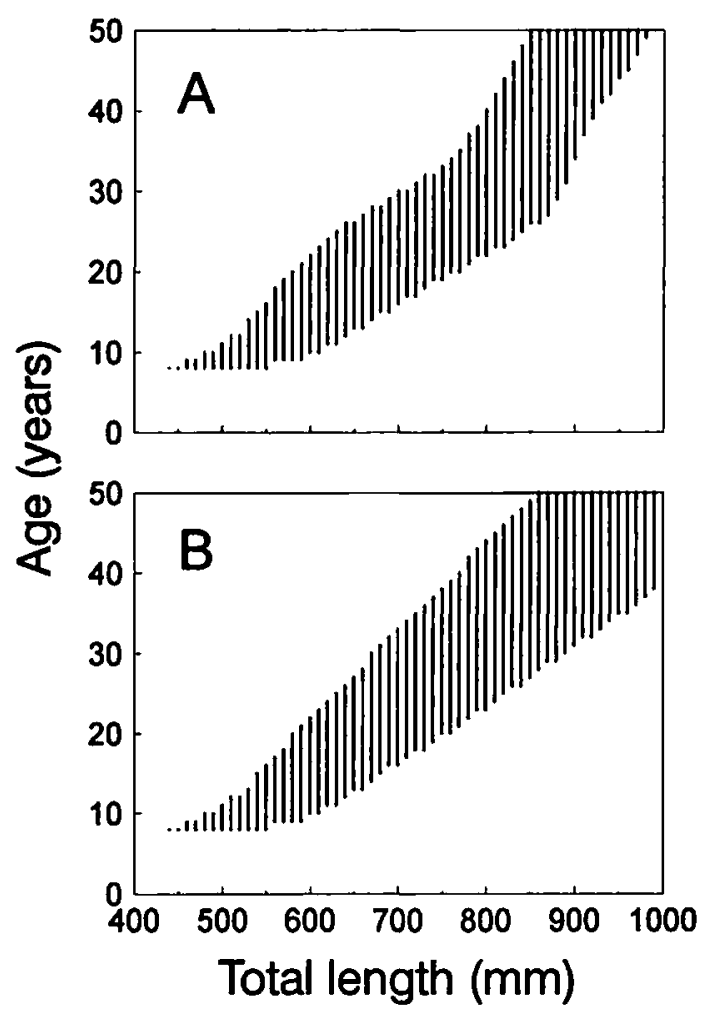

Figure 5.-Simulated range of estimated ages for Colorado squawtish of given length. Simulations used (A) size-specific growth rates as shown in Table 2 or (B) an assumed constant growth rate for fish $550 \mathrm{~mm}$ $\mathrm{TL}$ and longer. Bars in both graphs represent ages of $95 \%$ of fish of each length group.

$<0.05$ ). Only a narrow range of estimates was not significantly different from the measured distribution, even with $P<0.001$ (Figure 6 ). The best fit for the measured distribution was for a survival rate of 0.85 (Figure 7). Similar but broader ranges of survival were estimated for individual years, largely a result of smaller sample sizes. All years combined produced a range of suitable survival rates that narrowed to $0.82-0.87$ (Table 3 ). For a growing or declining population with a stable age distribution, the effect on survival rate would be a change of $\approx 1.0 \%$ for each $1.0 \%$ in population increase or decrease (Table 4). Estimated survival rates were the same when growth rates for fish $\mathbf{5 5 0}$ $\mathrm{mm}$ and longer used in calculation of stable length distributions varied by fish size (as in Table 2) or when assumed to be constant (as in Figure 4b). Twenty simulations of stable age distributions that used different random-number sequences produced identical suitable survival rates and nearly identical $\mathrm{K}-\mathrm{S} d$-value statistics. 


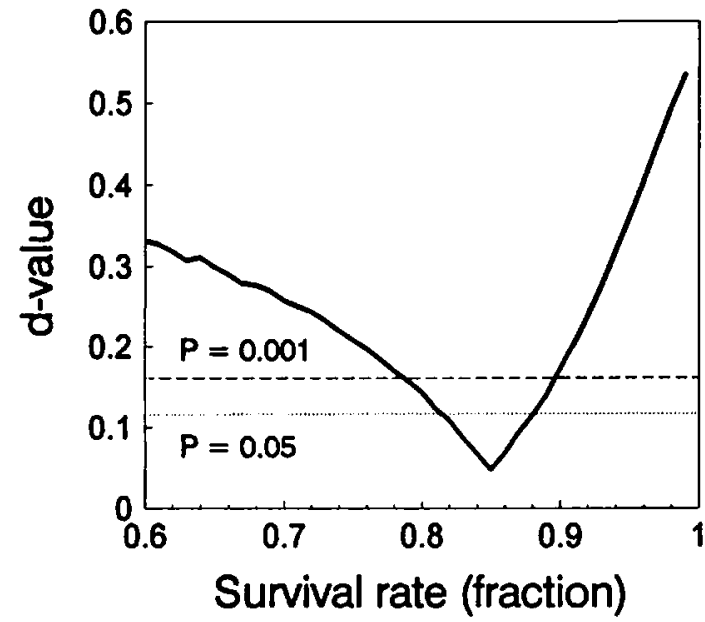

FIguRE 6.-Kolmogorov-Smirnov $D$-statistic for test between stable size distributions and measured size distributions for Colorado squaw fish $550 \mathrm{~mm}$ TL and longer captured during 1991-1994. Dotted lines represent maximum $d$-value ( $D$-statistic) for $P=0.001$ and $P=$ 0.05 . Lesser $d$-values have lower significance levels. Examples of observed and theoretical length distributions of three survival rates and associated statistics are in Figure 7 .

\section{Discussion}

\section{Growth, Age, and Size}

As expected, our estimates of growth rates and mean lengths by age-class were similar to those based on scale analyses reported by Seethaler (1978) and Hawkins (1992) up to ages 8-10 (Figure 3), given that our analyses through age 7 was also based on scales. Mean lengths at a given age were nearest to those of Seethaler (1978), though his estimates were slightly lower. This may reflect differences in the annual reference point: mid winter for Seethaler and mid to late spring for this study. A $13^{\circ} \mathrm{C}$ threshold in water temperature for Colorado squawfish growth (Osmundson 1987; Kaeding and Osmundson 1988) is attained in our study area in March or April, providing 1-3 months of additional growth for fish measured in mid-April to late June compared with estimated lengths at annulus formation in midwinter.

Results of scale analysis and additive recapture increments diverge after fish are 10 years old. Seethaler's (1978) and Hawkins' (1992) scalebased Colorado River results ended at ages 11 and 12 , respectively; however, the latter's pooled data from upper-basin rivers continued through age 18 . All earlier curves indicated high and relatively constant growth rates through the last years examined, whereas our estimated rates are lower af-

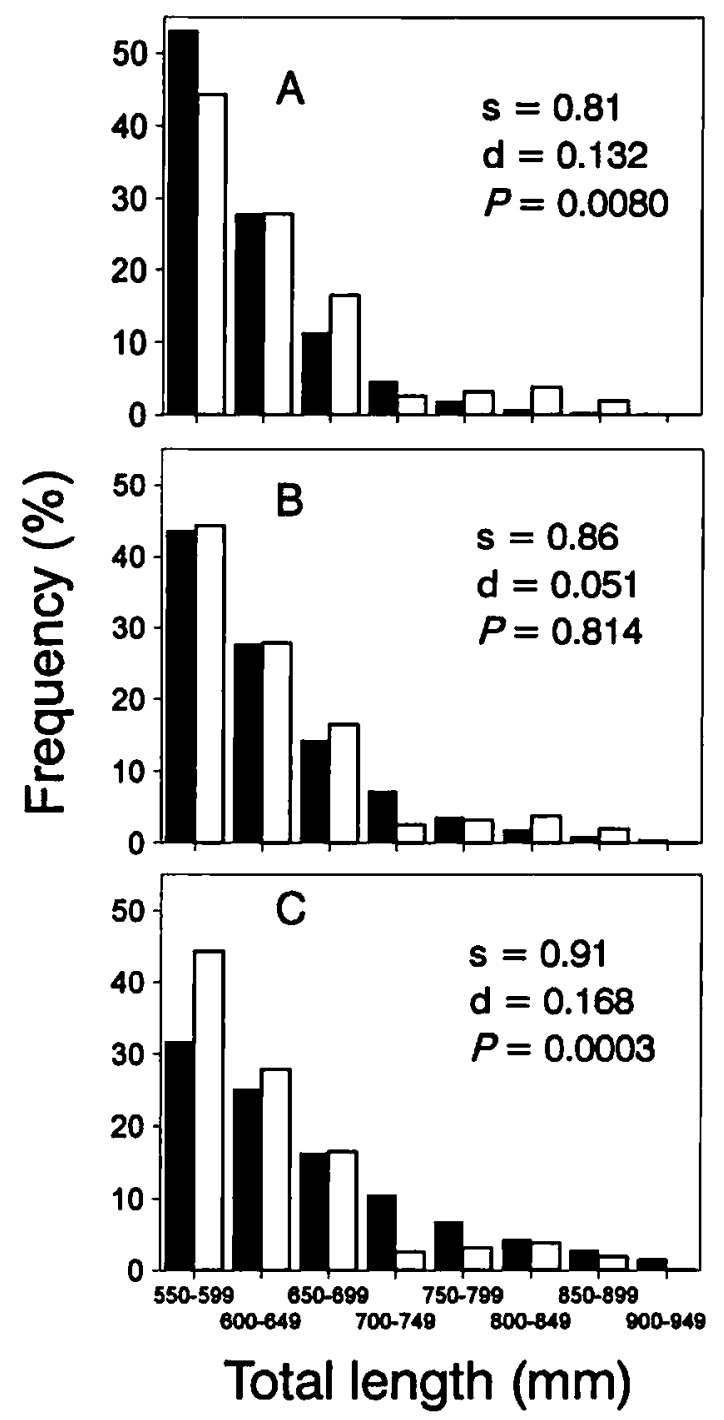

Figure 7.-Stable length distributions (black) and measured length distributions (white) during 1991-1994 for Colorado squawfish. Graphs show stable length distributions assuming survival rates $(s)$ of (A) 0.80 : (B) 0.85 ; and (C) 0.90 . Maximum $d$-values from Kolmogorov-Smirnov one-sample tests and associated probability levels $(P)$ are shown.

ter fish attain about $550 \mathrm{~mm}$ (Figure 3). We concur with Hawkins' (1992) caution that scale-based estimations are probably unreliable for Colorado squawfish beyond about age 10 .

Our estimates of mean annual increments from tagged and recaptured adults are similar to reports by others. Tyus (1988) recorded an average gain of $10.2 \mathrm{~mm}(\mathrm{SD}=11.3 \mathrm{~mm})$ in length per year for recaptured adults $(N=59 ; 482-770 \mathrm{~mm} \mathrm{TL})$ 
TABLE 3.-Survival rates of Colorado squawfish 550 $\mathrm{mm}$ total length and longer for which stable length distribution did not differ from measured distribution (Kolmogorov-Smirnov one-sample test. $P>0.05$ ).

\begin{tabular}{lcc}
\hline \multicolumn{1}{c}{ Year } & $N$ & Survival rate \\
\hline 1982 & 48 & $0.82-0.92$ \\
1990 & 15 & $0.60-0.91$ \\
1991 & 34 & $0.82-0.94$ \\
1992 & 41 & $0.83-0.87$ \\
1993 & 49 & $0.74-0.86$ \\
1994 & 34 & $0.74-0.91$ \\
1995 & 44 & $0.75-0.88$ \\
$1991-1994$ & 158 & $0.83-0.87$ \\
All years & 265 & $0.82-0.87$ \\
\hline
\end{tabular}

in the Green and Yampa rivers, and Hawkins (1992) reported $10-15 \mathrm{~mm}$ for fish longer than 500 $\mathrm{mm}$ TL from various rivers. Direct comparisons are difficult because annual increments vary with fish size and because the proportion of earlier samples consisting of faster-growing small adults is unknown. However, when we pooled increments from all our fish $450 \mathrm{~mm}$ TL and longer $(N=$ 121), mean annual growth was $14.4 \mathrm{~mm}$ ( $\mathrm{SE}=$ $1.2 \mathrm{~mm}$ ); for fish $500 \mathrm{~mm}$ and longer $(N=104)$, mean annual growth was $11.9 \mathrm{~mm}(\mathrm{SE}=1.0 \mathrm{~mm})$. Thus, estimates from earlier studies that used Carlin-tagged fish were similar to those that used PITtagged fish, and suspicions of negative effects on growth from dangler tags seem unfounded. An average annual growth increment of $30 \mathrm{~mm}$ estimated from back calculation of scale radii (Hawkins 1992) appears too high, except for fish less than $500 \mathrm{~mm}$, suggesting an upper size limit for using scales to estimate growth of Colorado squawfish. It is important to note that our estimates of growth rates of adults were mostly made from fish living in the upper reach; adults that remain in the lower reach could experience higher growth rates (provided food is sufficient) because of warmer water temperatures.

Using our method, we noted a decline in growth rate after fish reached about $550 \mathrm{~mm}$ and an increase after fish reached about $650 \mathrm{~mm}$ (Figure 3). The difference was not statistically significant, which may have resulted from small sample size of larger recaptured fish. Hawkins (1992) also noted increased growth rate at about $650 \mathrm{~mm}$ TL in both back-calculated scale and recapture data. If this phenomenon is real, as we suspect, it suggests an increase in food availability at this size; this could result from increased gape size or more effective foraging and handling ability allowing use of larger and more abundant prey. Alternatively,
TABLE 4.-Survival rates of Colorado squawfish 550 $\mathrm{mm}$ total length and longer for which stable length distribution did not significantly differ from measured distribution for years 1991-1994 (Kolmogorov-Smirnov [K-S] one-sample test, $P>0.05, N=158$ ) for annual population growth rates from -10 to $10 \%$. "Best estimate" is the survival rate with smallest $K-S D$-statistic and greatest $P$-value.

\begin{tabular}{ccc}
\hline $\begin{array}{c}\text { Growth } \\
\text { rate (\%) }\end{array}$ & Survival rate & Best estimate \\
\hline 10 & $0.93-0.97$ & 0.95 \\
5 & $0.88-0.92$ & 0.90 \\
0 & $0.83-0.87$ & 0.85 \\
-5 & $0.80-0.83$ & 0.81 \\
-10 & $0.76-0.80$ & 0.77 \\
\hline
\end{tabular}

differential growth and survival rates between sexes could explain an increased growth rate for fish about $650 \mathrm{~mm}$. However, because sexing Colorado squawfish in the field is unreliable, assessing growth rates by sex was not feasible.

Although variation among individuals exists, most fish do not grow consistently faster or slower than average in successive years, and average growth rates do not differ greatly among years. Nevertheless, there can be large differences among individuals in time to a given length, e.g., 20-year range of potential ages at a given length for fish greater than $800 \mathrm{~mm}$. Although length is therefore a poor indicator of age, we conclude that the population's largest fish are quite old. For individuals $900 \mathrm{~mm}$ TL, 34 years might be a minimum age, but an average would likely be 47-55 years (Figures $3,4 a$ ). Such fish are very rare. Of about 1,080 subadult and adult Colorado squawfish captured from the Colorado River during 1979-1995 only three $(0.28 \%)$ were greater than $900 \mathrm{~mm}$; two of these were less than $905 \mathrm{~mm}$ (C. McAda, USFWS, unpublished data). The largest, captured in 1990 by UDWR biologists, was $960 \mathrm{~mm}$. Exceptional longevity is probably a life history strategy that allows this and some other western cyprinid and catostomid species to survive periods of limited reproduction or recruitment when adverse environmental conditions are prolonged (Scoppettone and Vinyard 1991).

Although exhibiting declining growth rates with length, adults recaptured in our study did not stop growing. Of 69 fish greater than $550 \mathrm{~mm}$ later recaptured, only three exhibited no growth between years, and all of the largest fish captured (850-899 mm) exhibited growth between captures. If Colorado squawfish do stop growing at a certain age or length, cessation of growth may not 
be reached by most individuals in the present population. Natural mortality probably occurs before these fish reach that point.

There are anecdotal accounts of Colorado squawfish historically reaching $1,200-1,800 \mathrm{~mm}$ TL in the upper Colorado River basin (upstream of Lees Ferry, Arizona), a length considerably larger than that of any Colorado squaw fish caught in the past 20 years (e.g., Jordan 1891; Quarterone 1993). Two explanations proposed for the absence of such individuals are that the growth rate has declined or that the survival rate is reduced. Behnke and Benson (1983) suggested that the extirpation of bonytail Gila elegans has impacted the food supply of Colorado squawfish, thereby reducing growth. Gilpin (1993) showed with simulations that average and maximum sizes would significantly increase if adult survival rate was increased to 0.95 , and he suggested that rates have declined through angling mortality. Neither hypothesis, however, adequately explains the disappearance of very large individuals. Kaeding and Osmundson (1988) concluded that slow growth in the upper Colorado River basin was an historic norm because temperature regimes have, with few local exceptions, remained unchanged and potential foods, such as native Gila species and suckers, remain plentiful. Forage for young Colorado squawfish may even be greater than in the past because of the addition of non-native minnows. Also, size structure of Gilpin's simulated population with a survival rate of 0.95 indicated the largest individuals would not exceed $1,000 \mathrm{~mm}$ TL.

We offer a third hypothesis. Large fish may have attained their size in the lower Colorado River basin (downstream of Lees Ferry) and later moved upstream where they were eventually captured. Kaeding and Osmundson (1988) demonstrated that longer growing seasons and warmer temperatures in the lower basin historically provided 1.5-2.3 times the annual thermal units for growth than in upper basin reaches. Additionally, Colorado squawfish are capable of long-distance movements: radio-tagged adults have traversed the entire length of their current range in the upper Colorado River $(313 \mathrm{~km})$ in less than 3 months (McAda and Kaeding 1991), and similarly long spawning migrations in the Green River have been reported (Tyus 1990). If the lower basin was once a source of upper basin large fish, blockage of upstream movement by main-stem dams and eventual extirpation of downstream populations may explain the disappearance of very large individuals.

\section{Survival}

Our range of suitable $(P<0.05)$ survival estimates of $0.83-0.87$ (1991-1994 data) is higher than the estimate of Gilpin (1993) for the Green River population $(0.81)$, which may reflect differences in environment between the two rivers. However, had the methodology used by Gilpin (1993) provided a range rather than a point estimate, it may well have overlapped ours, suggesting no difference in survival rates. Deviations from a stable population size in either river would affect comparability of estimates because each was based on that assumption. Our estimates of survival were also higher than that $(0.65$ for females; 0.80 for males) found for the piscivorous walleye Stizostedion vitreum in a lightly harvested population (Schneider et al. 1977).

Our method of determining survival rate was not designed to replace capture-recapture models for open populations, such as Jolly-Seber (Jolly 1965; Seber 1965) and variations thereof. It can be applied, however, when the consistent capture effort and long capture histories necessary for Jolly-Seber modeling (see Pollock et al. 1990) are unavailable. Chief limitations of our method are a need for population structure data over several years and capture methods that sample varioussized fish at rates representing the actual population. Our tests indicated that population size structure of Colorado squawfish $550 \mathrm{~mm}$ and longer did not change significantly during 1990-1995 and was similar to that in 1982 . We were unable to test for capture bias in trammelnetting, but disproportionate numbers of large fish were caught by electrofishing, consistent with known biases of that gear type (Reynolds 1983). When captures by electrofishing were included in the analysis, estimated survival increased, as expected (not shown).

Though historic survival rates are unknown, there are new sources of mortality that may have recently lowered rates, although other sources of mortality are probably unchanged. Accidents during high water (abrasions, strandings, etc.), stress during spawning, and predation by great blue herons (Ardea herodias) and bald eagles (Haliaeetus leucocephalus) must have been primary sources of adult mortality. Significant change in these factors is unlikely, except perhaps the frequency of strandings, which may have increased because of excavation of floodplain gravel pits. Colorado squawfish are attracted to such habitats during 
spring runoff, and strandings have been documented (FWS, unpublished data) when declining flows reisolate the pits. Angling and netting by settlers and residents from the 1890s through the 1950s (Quarterone 1993) may have boosted mortality, though aboriginal harvest may also have been substantial. Anglers today fish primarily for introduced channel catfish Ictalurus punctatus, and mortality of Colorado squawfish from incidental catches occur, particularly in Colorado's Grand Valley, where the river bisects an urban area (FWS, unpublished data). Although the scope of anglingrelated mortality is unknown, it has probably been reduced during the past 20 years through educational efforts and the penalties associated with harming a protected species.

New factors to which Colorado squawfish may be subjected include parasitic diseases and ingestion of channel catfish. Although some parasites have been introduced, none is believed fatal (Secthaler 1978). Numerous anglers have, however, reported dead Colorado squawfish with channel catfish with spines extended lodged in the pharynx or esophagus (Vanicek and Kramer 1969; Quarterone 1993). The probability of encountering any dead Colorado squawfish is low, and the fact of several such reports suggests a common occurrence. McAda (1983) and Pimental et al. (1985) extracted channel catfish from the mouths of living Colorado squawfish, and several large Colorado squawfish captured during our study had gular perforations or slits, suggesting past encounters with channel catfish spines. Because channel catfish are abundant and ubiquitous in the area, the likelihood of a long-lived piscivore eventually eating one is high. We suspect that this is an important source of Colorado squawfish mortality.

The population viability analysis (PVA) of Gilpin (1993) on Green River Colorado squawfish identified information gaps that if filled, would strengthen future PVAs or other assessments dependent on demographic data. Growth and survival rates were identified as needing more accurate estimates. This work is a step toward fulfilling that need.

\section{Acknowledgments}

We thank Mike Tucker, Tom Fresquez, Dale Ryden, and Bruce Bonar for assisting with data collection; Frank Pfeifer for administrative support; Bob Burdick, Chuck McAda, Meredee Lloyd (U.S. Fish and Wildlife Service, FWS) and Bill Elmblad (Colorado Division of Wildlife) for sharing their respective data sets; and Tom Chart and Melissa
Trammell (Utah Division of Wildlife Resources) for exchanging data on individual fish we each captured at different times. We also thank Dave Propst, Rich Valdez, Kevin Bestgen, John Hawkins, and three anonymous reviewers for valuable comments on earlier versions of this manuscript. This research was funded by the FWS and the Recovery Implementation Program for Endangered Fish Species in the Upper Colorado River Basin.

\section{References}

Anderson, R. O., and S. J. Gutreuter. 1983. Length. weight. and structural indices. Pages $283-300$ in L. A. Nielsen and D. L. Johnson, editors. Fisheries techniques. American Fisheries Society. Bethesda, Maryland.

Beamish, R. J., and G. A. McFarlane. 1983. The forgotten requirement for age validation in fisheries biology. Transactions of the American Fisheries Society $112: 735-743$.

Beamish. R. J., and G. A. McFarlane. 1987. Current trends in age determination methods. Pages 15-24 in R. C. Summerfelt and G. E. Hall, editors. Age and growth of fish. Iowa State University Press, Ames.

Behnke, R. J.. and D. E. Benson. 1983. Endangered and threatened fishes of the upper Colorado River basin. Colorado State University, Cooperative Extension Service, Bulletin 503A. Fort Collins.

Belknap, B., and B. Belknap. 1974. Canyonlands river guide. Westwater Books. Boulder City. Nevada.

Burdick. B. D., and R. L. Hamman. 1993. A study to evaluate several tagging and marking systems on the Colorado squawfish, razorback sucker, and bonytail. U.S. Fish and Wildlife Service. Final Report, Grand Junction, Colorado.

Carlander. K. D. 1969. Handbook of freshwater fishery biology, volume 1. Iowa State University Press, Ames.

Carline. R. F., and O. M. Brynildson. 1972. Effects of the Floy anchor tag on the growth and survival of brook trout (Salvelinus fontinalis). Journal of the Fisheries Research Board of Canada 29:458-460.

Gilpin. M. 1993. A population viability analysis of the Colorado squawfish in the upper Colorado River basin. Report of Department of Biology. University of San Diego, to U.S. Fish and Wildlife Service. Denver, Colorado.

Hawkins, J. A. 1992. Age and growth of Colorado squawfish from the upper Colorado River basin. 1978-1990. Master's thesis. Colorado State University, Fort Collins.

Jolly, G. M. 1965. Explicit estimates from capturerecapture data with both death and immigrationstochastic model. Biometrika 52:225-247.

Jordan, D. S. 1891. Report of explorations in Colorado and Utah during the summer of 1889, with an account of the fishes found in each of the river basins examined. U.S. Fish Commission Bulletin 9:1-40. 
Kaeding, L. R., and D. B. Osmundson. 1988. Interaction of slow growth and increased early-life mortality: an hypothesis on the decline of Colorado squawfish in the upstream regions of its historic range. Environmental Biology of Fishes 22:287-298.

McAda, C. W. 1983. Colorado squawfish, Ptychocheilus lucius (Cyprinidae), with a channel catfish, Ictalurus punctatus (Ictaluridae), lodged in its throat. Southwestern Naturalist 28:119-120.

McAda, C. W., and L. R. Kaeding. 1991. Movements of adult Colorado squawfish during the spawning season in the upper Colorado River. Transactions of the American Fisheries Sociely 120:339-345.

McCarthy, M. S., and W. L. Minckley. 1987. Age estimation for razorback sucker (Pisce: Catostomidae) from Lake Mohave, Arizona and Nevada. Journal of the Arizona-Nevada Academy of Science 21:8797.

Mourning, T. E., K. D. Fausch, and C. Gowan. 1994. Comparison of visible implant tags and Floy anchor tags on hatchery rainbow trout. North American Journal of Fisheries Management 14:636-642.

Osmundson, D. B. 1987. Growth and survival of Colorado squawfish (Prychocheilus lucius) stocked in riverside ponds, with reference to largemouth bass (Micropterus salmoides) predation. Master's thesis. Utah State University, Logan.

Osmundson. D. B., and L. R. Kaeding. 1989. Studies of Colorado squawfish and razorback sucker use of the '15-mile reach' of the upper Colorado River as part of conservation measures for the Green Mountain and Ruedi reservoir water sales. U.S. Fish and Wildlife Service, Final Report, Grand Junction, Colorado.

Pimental, R., R. V. Bulkley, and H. M. Tyus. 1985. Choking of Colorado squawfish, Prychocheilus Iucius (Cyprinidae), on channel catfish, Ictalurus punctatus (Ictaluridae), as a cause of mortality. Southwestern Naturalist 30:154-158.

Pollock, K. H., J. D. Nichols, C. Brownie, and J. E. Hines. 1990. Statistical inference for capture-recapture experiments. Wildlife Monographs 107.

Quarterone, F. 1993. Historical accounts of upper Colorado River basin endangered fish. Colorado Division of Wildlife. Final Report, Denver.

Reynolds. J. B. 1983. Electrofishing. Pages 147-163 in L. A. Nielsen and D. L. Johnson, editors. Fisheries techniques. American Fisheries Society, Bethesda, Maryland.

Ricker, W. E. 1975. Computation and interpretation of biological statistics of fish populations. Fisheries Research Board of Canada Bulletin 191.

Schneider, J. C.. P. H. Eschmeyer, and W. R. Crowe. 1977. Longevity, survival, and harvest of tagged walleyes in Lake Gogebic, Michigan. Transactions of the American Fisheries Society 106:566-568.

Scoppettone, G. G. 1988. Growth and longevity of the cui-ui and longevity of other catostomids and cyprinids in western North America. Transactions of the American Fisheries Society 117:301-307.

Scoppettone, G. G., and G. Vinyard. 1991. Life history and management of four endangered lacustrine suckers. Pages 359-377 in W. L. Minckley and J. E. Deacon, editors. Battle against extinction: native fish management in the American west. University of Arizona Press, Tucson.

Seber, G. A. F. 1965. A note on the multiple-recapture census. Biometrika 52:249-259.

Seber, G. A. F. 1982 . The estimation of animal abundance. Macmillan, New York.

Seethaler, K. H. 1978. Life history and ecology of the Colorado squawtish (Ptychocheilus lucius) in the upper Colorado River basin. Master's thesis. Utah State University, Logan.

Snyder, D. E. 1981. Contributions to a guide to the cypriniform fish larvae of the upper Colorado River system in Colorado. Report of Larval Fish Laboratory, Colorado State University, to U.S. Bureau of Land Management, Biological Sciences Series 3. Denver, Colorado.

Tesch, F. W. 1968. Age and growth. IBP (International Biological Programme) Handbook 3:93-121.

Tranquilli, J. A., and W. F. Childers. 1982. Growth and survival of largemouth bass tagged with Floy anchor tags. North American Journal of Fisheries Management 2:184-187.

Tyus, H. M. 1988. Long term retention of implanted transmitters in Colorado squawfish and razorback suckers. North American Journal of Fisheries Management 8:264-267.

Tyus, H. M. 1990. Potamodromy and reproduction of Colorado squawfish in the Green River basin. Colorado and Utah. Transactions of the American Fisheries Society 119:1035-1047.

Vanicek, C. D.. and R. H. Kramer. 1969. Life history of the Colorado squawfish. Prychocheilus lucius, and the Colorado chub, Gila robusta, in the Green River in Dinosaur National Monument, 1964-1966. Transactions of the American Fisheries Society 98: 193-208.

Received July 1, 1996 Accepted February 6. 1997 